О. М. Ільницька, В. Ю. Катеринюк, О. Г. Катеринюк, Н. Д. Хороб ДВНЗ “Івано-Франківський національний медичний університет”

\title{
АКТУАЛЬНІСТЬ ПІСЛЯДИПЛОМНОЇ ОСВІТИ МЕДИЧНИХ ПРАЦІВНИКІВ У ДЕРЖАВНИХ ЗАКЛАДАХ ОХОРОНИ ЗДОРОВ'Я УКРАЇНИ (1 повідомлення)
}

\author{
O. M. Ilnitskaya, V. Yu. Katerynyuk, O. G. Katerynyuk, N. D. Horob \\ Ivano-Frankivsk National Medical University
}

\section{ACTUALITY OF POSTGRADUATE EDUCATION OF MEDICAL WORKERS IN STATE HEALTH CARE INSTITUTIONS OF UKRAINE}

\section{(1 message)}

\begin{abstract}
Мета роботи - розкриття правової регламентації післядипломної освіти медичних працівників у державних закладах охорони здоров’я України, яка впливає на правову компетентність лікарів.

Основна частина. У статті розглянуто поняття про правову регламентацію та реформування післядипломної підготовки медичних працівників у державних закладах охорони здоров’я України, у процесі якої планується прийняття багатьох нових законів, створення ефективної національної правової системи, що є об’єктивним процесом підготовки нового покоління працівників до забезпечення якості вищої медичної освіти, оскільки кожний лікар повинен вчитися протягом всього свого життя, для того, щоб удосконалюватися у професійному розвитку та бути хорошим спеціалістом. Також розглядаються фактори, які впливають на належну правову компетентність лікарів.

Висновок. Правова складова післядипломної підготовки медиків для системи охорони здоров'я України полягає у професійній підготовці висококваліфікованих відповідальних кадрів для державного управління системою охорони здоров'я, спроможних розробляти, аналізувати і реалізовувати державну політику у сфері охорони здоров'я.
\end{abstract}

Ключові слова: післядипломна медична освіта; післядипломна підготовка медичних працівників у державних закладах охорони здоров’я України; правова компетентність лікарів.

The aim of the work - to reveal the legal regulation of postgraduate education of health workers in public health care institutions in Ukraine, which affects the legal competence of doctors.

The main body. The article deals with the concept of legal regulation and reforming of postgraduate training of health workers in public health care institutions in Ukraine, in the process of which is planned to adopt many new laws, the creation of an effective national legal system, which is an objective process of preparing a new generation of workers to ensure the quality of higher education, medical education, as each doctor must study throughout his life, in order to improve his professional development and be a good specialist. The factors that influence the proper legal competence of physicians are also considered.

Conclusion. The legal component of postgraduate medical training for the health care system of Ukraine is the training of highly skilled responsible personnel for public health management, capable of developing, analyzing and implementing public health policy.

Key words: postgraduate medical education; postgraduate training of medical staff in state health care institutions of Ukraine; legal competence of doctors.

Вступ. Останнім часом особливої актуальності набувають питання юридичного забезпечення медичної діяльності в Україні, в тому числі післядипломної освіти медичних працівників у державних закладах охорони здоров’я України. Це насамперед пов’язано з активним розвитком медичної практики, розробкою нормативно-правової бази щодо введення загальнообов'язкового державного соціаль- ного медичного страхування, застосуванням новітніх досягнень медичної науки та удосконаленням управлінської діяльності в галузі охорони здоров'я.

Зміни в медицині слід розпочинати із змін у системі медичної освіти та підготовки управлінських кадрів. Якщо в закладах охорони здоров'я будуть працювати освічені, інтелігентні, добросовісні фахівці і держава при цьому створюватиме всі необ-

() О. М. Ільницька, В. Ю. Катеринюк, О. Г. Катеринюк, Н. Д. Хороб 
хідні умови, в яких їх знання і праця будуть цінуватися, то з часом в Україні з'являться лікарі, які будуть гідними своєї професії.

Зокрема в Україні, як і в більшості сучасних країн, чим день, тим більше зростає потреба у кваліфікованих спеціалістах із високим рівнем освіченості та фахових знань. Зазначену потребу може бути задоволено шляхом створення правових, економічних, організаційних умов для підвищення якості вищої медичної освіти та рівня професійної підготовки медичних кадрів сфери охорони здоров'я.

Медична освіта забезпечується мережею медичних, фармацевтичних і стоматологічних коледжів, інститутів, академій та університетів, у яких здійснюється середня, спеціальна та вища фахова підготовка, перекваліфікація та вдосконалення майстерності, а також післядипломна освіта медичних кадрів.

Вища медична освіта в Україні повинна забезпечити високоякісну підготовку лікарів і $€$ важливою складовою реформування галузі охорони здоров’я та реалізації соціальних пріоритетів держави, оскільки від рівня первинної підготовки лікарів і кваліфікаційної підготовки шляхом безперервної освіти залежить якість надання медичної допомоги населенню країни. Сучасний розвиток медичної науки і практики зумовлює необхідність постійно вносити корективи в підготовку та підвищення кваліфікації медичних працівників із наближенням їх освіти до міжнародних стандартів [3].

Мета роботи полягає у розкритті правової регламентації післядипломної освіти медичних працівників у державних закладах охорони здоров’я України, яка впливає на правову компетентність лікарів. Також обгрунтовується необхідність професійної підготовки медичних кадрів в умовах реформування галузі охорони здоров'я та системи ї̈ державного управління в Україні. Модернізація системи вищої медичної освіти знаходиться у прямій залежності від реформування галузі охорони здоров'я, оскільки таке реформування може бути здійснено завдяки комплексу державних перетворень, серед яких удосконалення нормативно-правової бази, забезпечення належного фінансування системи охорони здоров’ я і вищої медичної освіти тощо.

Основна частина. Відповідно до визначення Всесвітньої федерації медичної освіти, післядипломна медична освіта $€$ тією фазою медичного навчання, під час якої лікарі набирають досвіду після отримання базової медичної кваліфікації.

Одним із головних напрямів діяльності держави $€$ охорона здоров’я, і відповідно пріоритетною є ді- яльність із забезпечення належного рівня вищої медичної освіти в країні. Модернізація та реформування системи вищої медичної освіти відбуваються відповідно до реформування галузі охорони здоров'я та освіти в країні. Тому, як зазначено в Національній стратегії розвитку освіти в Україні на 2012-2021 рр. [1], система освіти в Україні, зокрема і вища медична освіта, потребує модернізації управління. Управління освітою має здійснюватися на засадах інноваційних стратегій відповідно до принципів: сталого розвитку, створення сучасних систем освітніх проектів та моніторингу; розвитку моделі державно-громадського управління, посилення ролі та взаємодії усіх суб'єктів освітньої політики, у якій особистість, суспільство й держава стають рівноправними суб'єктами і партнерами [1]. У Концепції розвитку охорони здоров'я населення України, затвердженій Указом Президента України від 7 грудня 2000 р. № 1313/2000, зазначається, що “реформування кадрової політики в системі охорони здоров'я має бути спрямовано на здійснення підготовки фахівців за новими спеціальностями: медичний психолог, клінічний фармацевт, економіст охорони здоров'я, спеціаліст з інформатики охорони здоров'я, спеціаліст з експлуатації медичної техніки, менеджер охорони здоров’я” [2]. Відповідно до Концепції розвитку вищої медичної освіти в Україні, затвердженої наказом Міністерства охорони здоров’я (МО3) України та Академією медичних наук України від 12 вересня 2008 р. № 522/51, розвиток та реформування національної системи охорони здоров'я паралельно з упровадженням інноваційної діяльності в галузь потребує підготовки нового покоління висококваліфікованих менеджерів охорони здоров'я, керівників медичних навчальних закладів та медичних працівників.

Післядипломна підготовка лікарів регламентована наказом МОЗ України від 22.07.1993 р. № 166 “Про подальше удосконалення післядипломної підготовки лікарів (провізорів)”; від 17.03.1993 р. № 48 "Про порядок направлення на стажування лікарів і їх наступного допуску до лікарської діяльності”; від 19.12.1997 р. № 359 “Про подальше удосконалення атестації лікарів”; від 07.12.1998 р. № 346 “Про затвердження Переліку назв циклів спеціалізації та вдосконалення лікарів і провізорів у вищих закладах післядипломної освіти”; від 12.08.2009 р. № 588 "Про атестацію професіоналів з вищою немедичною освітою, які працюють в системі охорони здоров’я”; від 07.07.2009 р. № 484 “Про затвердження Змін до Положення про проведення іспитів на передатестаційних циклах". 
Приєднавшись 2005 р. до Болонського процесу, Україна еволюційно впроваджує засади Болонської декларації в післядипломну медичну освіту. Це вимагає відповідної нормативно-правової бази та використання такого багатоцільового освітнього механізму, як Європейська кредитно-трансферна система (ECTS). Запровадження системи набору кредитів 3 усіх видів професійної діяльності лікаря з метою допуску до іспитів для присвоєння певної лікарської категорії стане одним з етапів стандартизованої системи оцінювання рівня професійної компетентності фахівця [5]. Для цього МОЗ України вжило ряд системних заходів. Зокрема, створена концепція додипломної та післядипломної медичної освіти відповідно до вимог Всесвітньої федерації медичної освіти та основних положень Болонського процесу. Враховуючи результати всебічного обговорення у вищих медичних навчальних закладах, медичних асоціаціях, та серед лікарів, щодо впровадження системи набору балів лікарями з усіх видів медичної діяльності, МОЗ України видало наказ від 07.07.2009 р. № 484 "Про затвердження змін до положення про проведення іспитів на передатестаційних циклах”.

На сьогодні післядипломна освіта медичних працівників у державних закладах охорони здоров'я України здійснюється відповідно до статті 47 Закону України “Про освіту”, статті 10 Закону України “Про вищу освіту”, директивних документів МО3 та МОН України.

Можна сказати, що післядипломна освіта виступає одним із засобів їх соціального захисту та забезпечує потреби суспільства і держави у конкурентоспроможних фахівцях. Вона сприяє задоволенню інтересів громадян у постійному підвищенні професійного та кваліфікованого рівня і запобігає втратам продуктивних сил завдяки регулярному оновленню професійної підготовленості фахівців до сучасних умов суспільства.

Особливої актуальності правова складова післядипломної підготовки лікарів набуває з огляду на проведення в державі правової реформи, у процесі якої планується прийняття багатьох нових законів, створення ефективної національної правової системи, що дасть змогу Україні інтегруватися в Європейське правове поле, сформувати ефективні інститути громадянського суспільства та побудувати дійсно демократичну, соціальну, правову державу [4]. Тому слід запроваджувати використання сучасних медичних технологій, щоб спеціалісти мали змогу навчатися і працювати в єдиному професійному європейському просторі.
На необхідність наявності належної правової компетентності лікарів вказують різні фактори, ключовими з яких $€[6]$ :

- часті та суттєві зміни нормативно-правової бази 3 надання медичної допомоги;

- активний розвиток державної медицини;

- надання платних медичних послуг у державних та муніципальних лікувально-профілактичних закладах;

- розвиток добровільного медичного страхування; - можливість для пацієнта всіма доступними засобами, у тому числі й шляхом звертання до суду, захищати свої права при наданні медичної допомоги.

Медичних працівників системи охорони здоров'я в Україні готують на рівні післядипломної освіти. Професійна підготовка медичних кадрів вищих медичних навчальних закладів в умовах магістратури і програм підвищення кваліфікації є об’єктивним процесом підготовки нового покоління працівників до забезпечення якості вищої медичної освіти. Важливим $є$ узагальнення досвіду з підготовки управлінців галузі за магістерськими програмами за спеціальностями з управління в галузі охорони здоров’я. Це дасть змогу істотно вдосконалити наявну систему підготовки, перепідготовки та підвищення кваліфікації фахівців галузі охорони здоров'я, які б відповідали потребам суспільства та необхідності перебудови галузі охорони здоров'я в Україні. Отже, стає очевидною потреба в підготовці професійних медичних кадрів, включаючи їхню професійну підготовку та підвищення кваліфікації.

Післядипломна підготовка медичних працівників охорони здоров'я в Україні передбачає дотримання принципу безперервності навчання, основною метою якого $є$ забезпечення й підтримка високого професійного рівня фахівців в умовах прискореного розвитку науки та еволюції суспільних потреб у період суспільних та економічних трансформацій. Необхідний рівень кваліфікації медичних кадрів у галузі охорони здоров'я досягається шляхом поєднання різних видів навчання в навчальних закладах післядипломної освіти, а також системної самоосвіти та постійної практичної діяльності як медиків. В контексті реформування системи охорони здоров’я України питання підвищення рівня професіоналізму медичних працівників сфери охорони здоров’я стає особливо актуальним. Удосконалення управління сферою охорони здоров'я на всіх рівнях означає модернізацію інфраструктури, опрацювання системи визначення пріоритетів, ана- 
ліз та обгрунтування політики в галузі медичного забезпечення, об’єктивність і справедливість під час розподілу ресурсів, формування адекватного бюджету, підвищення кваліфікації та рівня професійної компетенції медиків сфери охорони здоров'я.

Таким чином, підвищення рівня правових знань у керівників різних рангів системи охорони здоров’я України, їх правової свідомості та правової культури можливі лише за умови системного та повсякденного, професійно організованого правового виховання, що здійснюється з використанням усіх його форм, у тому числі й за допомогою післядипломної підготовки медичних працівників у державному секторі.

Висновки. Професія лікаря передбачає постійне навчання протягом усієї трудової діяльності. Тому післядипломна підготовка медичних працівників у державному секторі - безперервний процес, який вимагає чіткого плану та суттєвих витрат часу.

\section{Список літератури}

1. Проект Національної стратегії розвитку освіти в Україні на 2012-2021 роки. - Режим доступу : http:// osvita-zm.org.ua.

2. Про Концепцію розвитку охорони здоров’я населення України : Указ Президента України від 7 груд. 2000 р. № 1313/2000. - Режим доступу : http://zakon2.rada.gov. ua/laws/show/ 1313/2000/print1393487955187495.

3. Москалик Г.Ф. Безперервна освіта та сучасний інформаційний простір / Г. Ф. Москалик // European cooperation. - 2015. - № 5. - C. 24-34.

\section{References}

1. Proekt Natsionalnoi stratehii rozvytku osvity v Ukraini na 2012-2021 roky [Draft National Strategy for the Development of Education in Ukraine for 2012-2021]. Access mode: http://osvita-zm.org.ua [in Ukrainian].

2. Pro Kontseptsiiu rozvytku okhorony zdorovia naselennia Ukrainy: Ukaz Prezydenta Ukrainy vid 7 hrud. 2000 r. № 1313/2000 [About the Concept of Health Care Development in Ukraine: Presidential Decree of 7 December. 2000 No. 1313/2000]. - Access mode: http://zakon2. rada.gov.ua/laws/show/ 1313/2000/print1393487955187495 [in Ukrainian].

3. Moskalyk, H.F. (2015). Bezperervna osvita ta suchasnyi informatsiinyi prostir [Continuing education and modern informational space]. Yevropeiska spivpratsia - European Cooperation, 5, 24-34 [in Ukrainian].
Саме тому навчальні програми формуються з урахуванням науково-технічного прогресу в медицині.

Таким чином, післядипломна освіта медиків полягає у спеціалізованому вдосконаленні освіти та професійної підготовки особи шляхом поглиблення, розширення і оновлення її професійних знань, умінь і навичок або отримання іншої спеціальності на основі здобутого раніше освітньо-кваліфікаційного рівня та практичного досвіду. Оскільки післядипломна освіта медичних працівників визначається вимогами суспільства до кадрового забезпечення галузей господарства з урахуванням перспективи їх розвитку. Тому правовою складовою післядипломної підготовки медиків для системи охорони здоров’я України є професійна підготовка висококваліфікованих відповідальних кадрів для державного управління системою охорони здоров'я, спроможних розробляти, аналізувати і реалізовувати державну політику у сфері охорони здоров’я.

4. Правознавство : підручник / [А. І. Берлач, Д. О. Карпенко, В. С. Ковальський та ін.] ; за ред. В. В. Копейчикова, А. М. Колодія. - К. : Брінком Інтер, 2005. - 752 с.

5. Савицкая П. Б. Последипломное обучение врачей скорой помощи: опыт и перспективы развития / П. Б. Савицкая // Проблеми сучасної медичної науки та освіти. - 2010. - № 1. - С. 11-13.

6. Стеценко С. Г. Медицинское право : учебник / С. Г. Стеценко. - Изд-во “Юридический центр Пресс", 2004. -572 c

4. Berlach, A.I., Karpenko, D.O., Kovalskyi, V.S., Kolodii, A.M., Oliinyk, A.Yu., \& Pidopryhora, O.O. (Eds.) Kopeichykova, V.V., \& Kolodiia, A.M. (2005). Pravoznavstvo: Pidruchnyk [Jurisprudence: Textbook]. Kyiv: Brinkom Inter [in Ukrainian].

5. Savitskaya, P.B. (2010). Posledyplomnoe obucheniye vrachey skoroy pomoshchi: opyt i perspektivy razvitiya [Postgraduate training of ambulance doctors: experience and development perspectives.]. Problemy suchasnoi medychnoi nauky ta osvity - Problems of Modern Medical Science and Education, 1, 11-13 [in Russian].

6. Stetsenko, S.G. (2004). Meditsynskoe pravo: Uchebnik [Medical law: Textbook]. Izd. "Yuridicheskiy tsentr Press" [in Russian]. 